\title{
Oxidative Stress Under Ambient and Physiological Oxygen Tension in Tissue Culture
}

\author{
Lakshmanan Jagannathan $^{1} \cdot$ Suresh Cuddapah ${ }^{1} \cdot$ Max Costa $^{1}$
}

Published online: 23 January 2016

(C) Springer International Publishing AG 2016

\begin{abstract}
Oxygen $\left(\mathrm{O}_{2}\right)$ levels range from 2-9\% in vivo. However, cell culture experiments are performed at atmospheric $\mathrm{O}_{2}$ levels $(21 \%)$. Oxidative stress due to generation of reactive oxygen species (ROS) in cells cultured at higher than physiological levels is implicated in multitude of deleterious effects including DNA damage, genomic instability, and senescence. In addition, oxidative stress activates redoxsensitive transcription factors related to inflammatory and apoptotic signaling. Furthermore, several chromatin-modifying enzymes are affected by ROS, potentially impacting epigenetic regulation of gene expression. While primary cells are cultured at lower $\mathrm{O}_{2}$ levels due to their inability to grow at higher $\mathrm{O}_{2}$, the immortalized cells, which display no such apparent growth difficulties, are typically cultured at $21 \% \mathrm{O}_{2}$. This review will provide an overview of issues associated with increased oxygen levels in in vitro cell culture and point out the benefits of using lower levels of oxygen tension even for immortalized cells.
\end{abstract}

Keywords Oxygen tension - Oxidative stress · Primary cells · Immortalized cells $\cdot$ Reactive oxygen species $\cdot$ Hypoxia

This article is part of the Topical Collection on Free Radicals Medicine

Suresh Cuddapah

suresh.cuddapah@nyumc.org

Max Costa

Max.Costa@nyumc.org

1 Department of Environmental Medicine, School of Medicine, New York University, 57 Old Forge Rd, Tuxedo, NY 10987, USA

\section{Introduction}

Aerobic life forms on earth adapted to progressively increasing oxidative environment and evolved with complex respiratory system to utilize and distribute oxygen to various organs and tissues. The partial pressure $\left(\mathrm{pO}_{2}\right)$ of ambient atmospheric oxygen is $150 \mathrm{~mm} / \mathrm{Hg}$, which is equivalent to $21 \%$ oxygen $\left(\mathrm{O}_{2}\right.$; normoxia). However, the inhaled $\mathrm{O}_{2}$ levels progressively decrease as it reaches various internal organs and tissues (Fig. 1). The level of $\mathrm{O}_{2}$ and its distribution among the various tissues depends on the rate of capillary blood flow and its metabolic activity (i.e., oxygen utilization) [1]. For instance, in humans, under physiological conditions, the $\mathrm{pO}_{2}$ in the arterial blood is $100 \mathrm{~mm} / \mathrm{Hg}$ or $14 \% \mathrm{O}_{2}$. When it reaches the well-irrigated parenchymal organs such as lungs [2-4], liver [5-7], and kidneys [8], the $\mathrm{O}_{2}$ levels ranges from 4 to $14 \%$. In the relatively less irrigated organs and tissues, including brain [9, 10], eye [11], and bone marrow [12], the $\mathrm{O}_{2}$ concentration ranges between 0.5 and $7 \%$. Moreover, gradient distributions of $\mathrm{O}_{2}$ within organs and developmental stage-specific $\mathrm{O}_{2}$ levels have also been observed [4, 7, 13-15]. Several pathophysiological conditions resulting from fluctuations in oxygen tension including (e.g., hyperoxiaassociated lung injury, hypoxia in cancer, and wound healing) has been well documented [16].

In vitro cultured cells (both non-immortalized primary cells and immortalized cells lines) are the preferred model system for studying cellular response to specific stimuli such as drug treatment and toxicity testing and to understand basic cellular mechanisms including differentiation and disease development. Cell lines provide cellular homogeneity, which is valuable for understanding molecular mechanisms including functional genomics. Moreover, studies on certain areas such as genetic disorders, neurological disorders, and genetic polymorphisms that may be uniquely human and thus not amenable to studying using animal models. In vitro cell culture is traditionally performed at $21 \% \mathrm{O}_{2}$, the $\mathrm{O}_{2}$ level in ambient 
Fig. 1 Oxygen distribution in various organs: The partial pressure $\left(\mathrm{pO}_{2}\right)$ of ambient atmospheric oxygen is $150 \mathrm{~mm} /$ $\mathrm{Hg}\left(21 \% \mathrm{O}_{2}\right)$. The inhaled $\mathrm{O}_{2}$ levels progressively decrease as it reaches various internal organs. The partial pressure of oxygen $\left(\mathrm{pO}_{2}\right)$ in the arterial blood is $100 \mathrm{~mm} / \mathrm{Hg}$ or $14 \% \mathrm{O}_{2}$. The $\mathrm{O}_{2}$ tension ranges from 4 to $14 \%$ in lungs, liver, and kidneys. In the relatively less irrigated organs and tissues, including brain, eye, and bone marrow, the $\mathrm{O}_{2}$ concentration ranges between 0.5 and $7 \%$

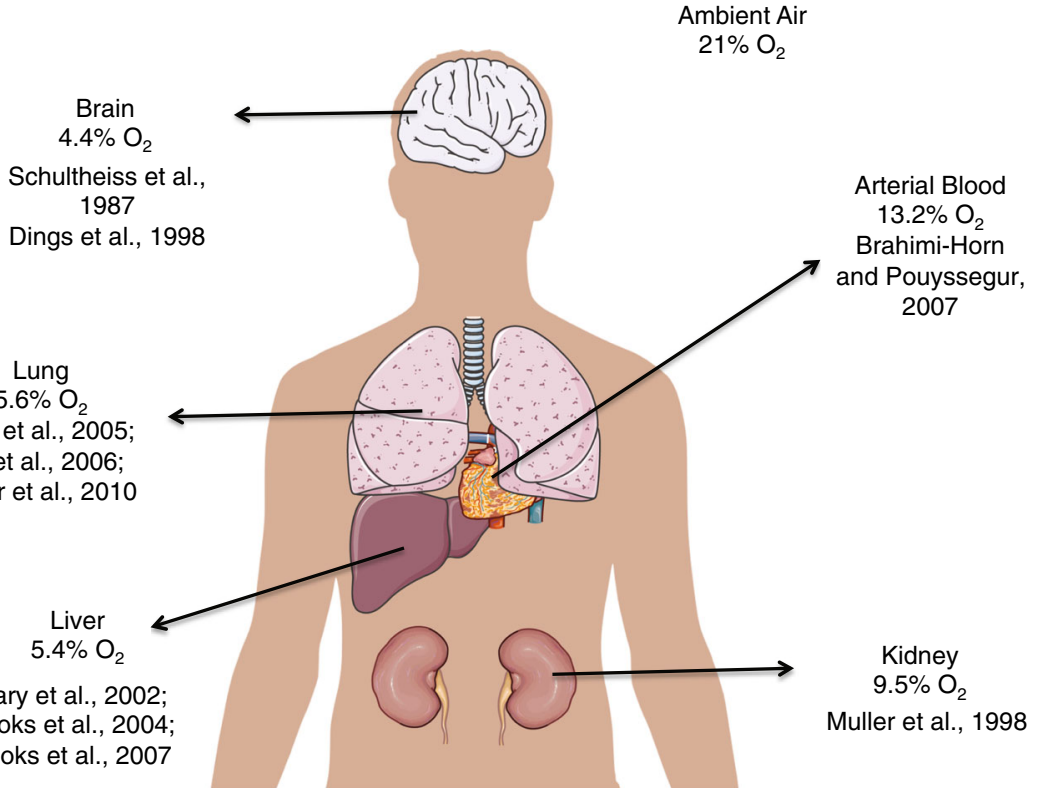

atmospheric air. Thus, the $\mathrm{O}_{2}$ levels in in vitro cultures are approximately 2-5-fold higher than the physiological $\mathrm{O}_{2}$ levels encountered by tissues in vivo [17, 18]. Accumulating evidence suggests that culturing non-immortalized primary cells or stem cells at lower physiologically relevant oxygen tension (physioxia or physiological normoxia) increases the replicative life span of the cells [19-21]. Therefore, primary cells are typically cultured at lower $\mathrm{O}_{2}$ levels $[18,22-24]$. However, unlike the primary cells, immortalized cells do not exhibit apparent growth difficulties at $21 \% \mathrm{O}_{2}$, likely due to its ability to evade replicative senescence $[25,26]$. Therefore, the detrimental effects of increased oxygen levels in immortalized cell cultures have been over-looked and growing these cells at $21 \% \mathrm{O}_{2}$ is currently a standard practice. Nevertheless, accumulating evidence suggests that abundant reactive oxygen species (ROS) and associated oxidative stress in cells cultured at high $\mathrm{O}_{2}$ levels could affect the physiology of cells in culture $[27,28]$, which could potentially influence the experimental outcome. The current review will provide an overview of issues associated with increased oxygen tension in in vitro cell culture and point out the benefits of using lower levels of oxygen tension even for immortalized cells.

\section{ROS Production in Tissue Culture}

Oxidative stress is an imbalance between the production of reactive oxygen species (ROS) such as superoxide anion $\left(\mathrm{O}_{2}{ }^{-}\right)$, hydroxyl radical ( $\left.{ }^{\circ} \mathrm{OH}\right)$, hydrogen peroxide $\left(\mathrm{H}_{2} \mathrm{O}_{2}\right)$, and singlet oxygen $\left({ }^{1} \mathrm{O}_{2}\right)$ and their detoxification, resulting in cellular damage. Most ROS are generated in cells by the mitochondrial respiratory chain. Mitochondrial ROS production is modulated largely by the rate of electron flow through respiratory chain complexes. Under physiological conditions approximately 1$4 \%$ of the oxygen consumed by mitochondria is diverted for the formation of ROS [29]. Considering that the average rate of utilization of oxygen in each cell of human body is $\sim 2.5 \times 10$ $18 \mathrm{~mol} / \mathrm{s}$ (i.e., $2.2 \times 10^{10} \mathrm{molecules} /$ day) [29], almost $\sim 1$ billion molecules of ROS are being produced by each cell every day in vivo [29]. This can be multiplied several fold under in vitro culture conditions which is cultured at $21 \% \mathrm{O}_{2}$ as compared to physiological conditions $\left(10-13 \% \mathrm{O}_{2}\right)$.

Although excess ROS can lead to oxidative stress, moderate to low levels of ROS function in cellular signaling pathways [30]. The mammalian system is naturally equipped to deal with oxidative stress. Antioxidants, including glutathione (GSH), vitamins $\mathrm{C}$ and $\mathrm{E}$, and antioxidant enzymes such as catalase, superoxide dismutase (SOD), and various peroxidases help to maintain the cellular redox environment. Recent evidence suggests that lower availability of antioxidants including vitamins $\mathrm{E}$ and $\mathrm{C}$ and selenium in cell culture medium could affect the cell's ability to efficiently scavenge ROS [31]. Moreover, the photochemical oxidation of flavonoids, thiols, and polyphenolic compounds in the cell culture media can produce $\mathrm{H}_{2} \mathrm{O}_{2}$ in cell culture [32]. Therefore, overproduction of ROS at $21 \% \mathrm{O}_{2}$ combined with impaired antioxidant system in cell culture conditions could contribute to cellular damage, inflammation, and senescence.

\section{Cellular Damage by ROS}

The deleterious effects of $21 \% \mathrm{O}_{2}$ on primary cells have been well documented [33]. Oxidative stress induces production of 
highly reactive free radicals, which cause irreversible damage to all biomolecules including DNA, proteins, lipids, and sugars [34]. The formation of peroxyl radicals and oxidation of cysteine residues during oxidative stress causes protein conformational changes, which ultimately affect their functions [35]. For instance, damage to protein kinases or phosphatases leads to dysregulation of signaling cascades, affecting a multitude of cellular functions. Protein folding in endoplasmic reticulum (ER) is catalyzed by disulfide isomerase that requires GSH for its functioning [36]. Over utilization of GSH during oxidative stress results in ER stress, causing in accumulation of unfolded proteins in the cytoplasm [36] and autophagy [37]. The most destructive effect of ROS is their ability to cause DNA damage [22, 38-41]. ROS can oxidize nucleotides and can cause single- and double-strand DNA breaks (SSBs and DSBs), and oxidatively generated non-DSB clustered DNA lesions (OCDLs) [38]. The addition of hydroxyl radical to the $\mathrm{C} 8$ position of guanine ring, produces the 8-hydroxy-7,8-dihydroguanyl radical that is further oxidized to 8-oxo-7,8-dihydroguanine (8-oxodG) and 2,6diamino-4-hydroxy-5-formamidopyrimidine (FapydG) [38] . The OCDLs are resistant to DNA repair process and can result in irreversible DNA damage [38, 41]. Interestingly, mouse stem cells cultured at $3 \% \mathrm{O}_{2}$ showed less oxidative stress and lower aneuploidy, compared to the cells cultured at $21 \% \mathrm{O}_{2}$ [42]. Increased neuronal cell survival and differentiation of human neural progenitor cells is observed in human umbilical cord Wharton jelly derived mesenchymal stem cells (hWJ-MSCs) cultured at lower oxygen tension as compared to normoxia [43, 44]. On the contrary, culturing cells at $21 \% \mathrm{O}_{2}$ is known to induce chromosomal abnormality/aberration [41, 45, 46], aneuploidy [42], telomere shortening [47], and DNA damage [22] at genome levels in primary cells.

\section{Activation of Redox-Sensitive Inflammatory Signaling}

Prolonged generation of reactive oxygen species (ROS) contributes to chronic inflammation [34]. Alternatively, chronic inflammation can also induce oxidative stress and reduce the cellular antioxidant capacity [34]. Freshly isolated human PBMCs at atmospheric oxygen levels $\left(21 \% \mathrm{O}_{2}\right)$ sent out inflammatory signals as though they were fighting off an infection. Interestingly, the same cells grown at lower oxygen levels $\left(5\right.$ and $10 \% \mathrm{O}_{2}$ ) displayed considerably reduced inflammatory signaling $[17,18]$. Human PBMCs response to stimulation with mitogens including conA and CD3/CD28 crosslinking is observed to be significantly higher at $20 \%$ oxygen tension, compared to 5 and $10 \%$ oxygen tensions $[17,18]$. The mitogen-induced PBMCs show increased intracellular nitric oxide levels and reduced intracellular glutathione levels at $20 \%$ oxygen $[17,18]$. Haddad et al., showed the increase in expression of genes involved in cell death, cellular repair, and stress response in primary $\mathrm{T}$ cells maintained at atmospheric $\mathrm{O}_{2}$ levels indicating increased oxidative stress response [48]. Cultivation of rat liver sinusoidal endothelial cells (LSECs) at $5 \% \mathrm{O}_{2}$, as opposed to $21 \% \mathrm{O}_{2}$ improved the survival of LSECs and scavenger receptor-mediated endocytic activity, reduced the production of the pro-inflammatory mediator, interleukin-6, and increased the production of the antiinflammatory cytokine, interleukin-10 [49]. Expression of the cell adhesion molecule, ICAM-1 at the cell surface was slightly more elevated in cells maintained at $21 \% \mathrm{O}_{2}$ [50], indicating activation of an inflammatory response.

Increase in secretion of pro-inflammatory cytokines in senescent cells suggests a crucial link between oxidative stress and inflammatory signaling [34]. A likely reason is that several inflammatory signaling events and transcription factors are redox-sensitive and would get manipulated by the alteration in the cellular redox potential [34,51]. Interestingly, the activation of different redox-sensitive transcription factors and the resultant biological response is correlated with the levels of ROS in the cells [34, 51] (Fig. 2). Low-sustained ROS level mainly induces the antioxidant and cellular detoxification program like the Kelch-like ECH-associated protein 1 (Keap1)NF-E2-related factor-2 (NRF2) regulatory pathway, which plays a key role in the protecting cells against oxidative and xenobiotic damage [52]. An intermediary amount of ROS triggers inflammatory response through the activation of NF-KB, STATs, and AP-1, transcription factors involved in the regulation of a wide array of genes involved in stress response, inflammation, immune function, differentiation, apoptosis, cell survival, and growth [53]. Finally, high levels of oxidative stress trigger disruption of electron transfer by inducing mitochondrial pore formation, thereby resulting in apoptosis or necrosis (Fig. 2). The effects of ROS on the cell are also partly mediated through activation of mitogen-activated protein kinases (MAPKs) [54, 55]. Recent studies show nonhypoxic activation of HIF- $1 \alpha$ via mitochondrial-derived ROS [56]. The ROS-induced activation of HIF- $1 \alpha$ might cross talk with redox sensitive transcription factors and signaling mechanisms, which could lead to tumor initiation.

\section{Cellular Immortality Requires Development of Oxidative Stress Resistance}

Primary cells exhibit growth difficulty at $21 \% \mathrm{O}_{2}$ due to the overproduction of ROS and the subsequent bio-molecular damage [39, 47, 57-59]. This poor growth response in high oxygen-treated cultures was abrogated by administration of catalase, which scavenges excessive $\mathrm{H}_{2} \mathrm{O}_{2}$ produced at $21 \%$ $\mathrm{O}_{2}$. This suggests that the toxic effects observed in high $\mathrm{O}_{2}$ environments are largely caused by endogenous production of $\mathrm{H}_{2} \mathrm{O}_{2}$ [39]. Moreover, treatment with low doses of $\mathrm{H}_{2} \mathrm{O}_{2}$ is 


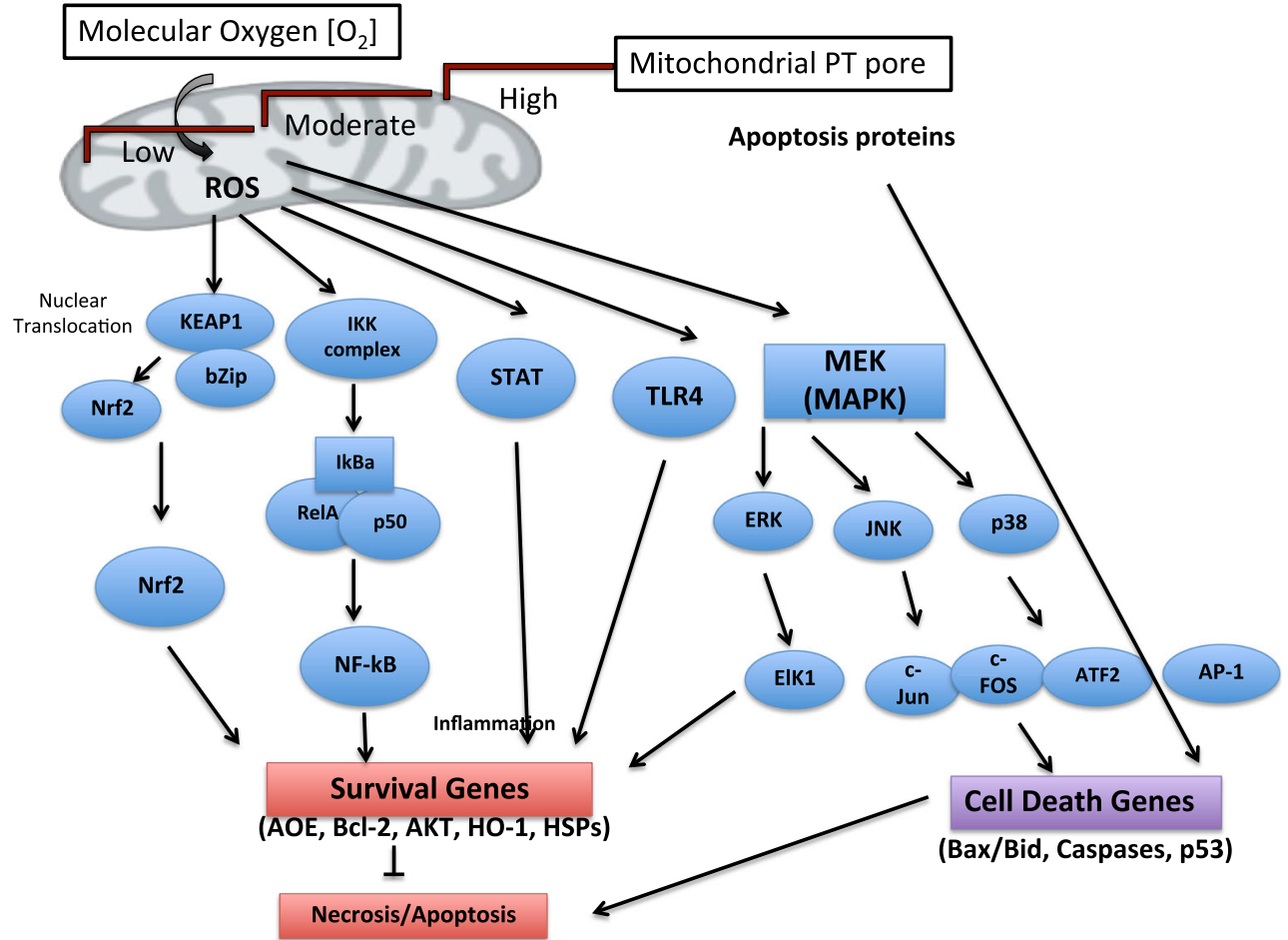

Fig. 2 Activation of redox sensitive inflammatory signaling: ROS activates inflammatory signaling via activation of redox sensitive transcription factors and signaling. The activation of different redoxsensitive transcription factors and the resultant biological response is correlated with the levels of ROS in the cells. Low-sustained ROS level mainly induces the antioxidant and cellular detoxification program like the Kelch-like ECH-associated protein 1 (Keap1)-NF-E2-related factor-2 (NRF2) regulatory pathway. An intermediary amount of ROS triggers

sufficient to induce replicative senescence in primary mouse embryonic cells [39]. Unlike primary cells, the effect of high $\mathrm{O}_{2}$-induced ROS in immortalized cells is less well studied. However, it is clear that immortalized cells suffer less oxidative damage compared to primary fibroblasts when cultured under $20 \% \mathrm{O}_{2}[60,61]$. Moreover, immortalized cells are shown to exhibit higher resistance to deleterious effect of $\mathrm{H}_{2} \mathrm{O}_{2}$ than primary cells $[60,61]$. Kondoh et al., showed an induction of immortality in primary cells selected for increased phosphoglycerate mutase (PGM) activity, which showed enhanced glycolytic-influx and resistance to oxidative stress $[61,62]$. Similarly, tumor cells show remarkable tolerance towards oxidative stress and utilize excessive glucose via anaerobic glycolysis to prevent the oxidative damage [60]. These studies suggest association of cellular immortalization with the development of resistance to oxidative stress, allowing them to grow at high $\mathrm{O}_{2}$ levels for extended periods. However, immortalized cells cultured at ambient atmospheric $\mathrm{O}_{2}$ levels showed redox imbalance, cell proliferation defects, and activation of NF- $\mathrm{kB} /$ RelA-mediated inflammatory signaling. Furthermore, the cells cultured at physiological $\mathrm{O}_{2}$ levels showed better ability to handle oxidative stress as compared to the cells cultured at ambient $21 \% \mathrm{O}_{2}$ levels [63]. Therefore, inflammatory response through the activation of NF- $\mathrm{BB}$, STATs, and AP-1 transcription factors associated gene expression. Finally, high levels of oxidative stress trigger disruption of electron transfer by inducing mitochondrial pore formation, thereby resulting in apoptosis or necrosis. The effects of ROS on the cell are also partly mediated through activation of mitogen-activated protein kinases (MAPKs). All these mechanism can induce multitude of downstream processes including inflammation, survival and apoptosis

although immortalized cells acquire the ability to grow under high $\mathrm{O}_{2}$ levels, the cellular damage due to oxidative stress and inflammation is not completely eliminated [63].

\section{ROS Mediates the Effects of Both Hypoxia and Hyperoxia}

While increasing oxygen concentration can influence the production of free radicals, decreasing it can lead to hypoxia. Hypoxia can lead to the production of oxygen radicals in a variety of experimental systems via electron attack of molecular oxygen in the inactive mitochondria [64-66]. It is interesting that oxidative stress and hypoxia, which are quite different scenarios in terms of total oxygen tension, can result in similar outcome due to production of the common mediator, ROS. Recently, it has become clear that under hypoxic conditions, the mitochondrial respiratory chain also produces nitric oxide (NO), which can generate other reactive nitrogen species (RNS) [30]. Oxidative stress and hypoxia are serious consequences of many diseases such as cancer, heart disease, inflammation, COPD, and many others. 
Hypoxia plays a major role in the pathology of several human diseases, including cancer, diabetes, aging, and stroke/ischaemia $[67,68]$. Under hypoxia, the hypoxia inducible factors (HIF) family of transcription factors becomes activated. The members of the HIF family transcription factors, HIF- $1 \alpha$, HIF- $2 \alpha$, and HIF- $3 \alpha$, are oxygen labile and can heterodimerize with the oxygen insensitive HIF-1 $\beta$, also known as aryl hydrocarbon nuclear translocator (ARNT) [68]. Under normal oxygen tension (normoxia), the proline residues in the oxygen-dependent domain of HIF is hydroxylated by a family of dioxygenases, called prolylhydroxylases (PHDs) (oxygen sensors) [69]. The hydroxylated proline residues are recognized by von Hippel-Lindau (VHL), which subsequently recruit an E3 ubiquitin ligase complex and target HIF for degradation [70]. Another dioxygenase, factor inhibiting HIF (FIH) can also influence HIF activity. The enzymatic activities of both PHDs and FIH require oxygen, $\alpha$-ketoglutarate, iron $\left(\mathrm{Fe}^{2+}\right)$, and ascorbate as cofactors. Depletion of any of these cofactors, as well as oxidative stress mediated Fe oxidation, can inhibit enzymatic activity and stabilize the HIFs.

\section{ROS Mediates Epigenetic Dysregulation in Both Hypoxia and Hyperoxia}

ROS produced during both hypoxia and hyperoxia has profound effects on epigenetic modification. A number of 2oxoglutarate dependent dioxygenases that demethylate histone tails or hydroxylate the 5-position cytosine of DNA use oxygen for their enzymatic activity. These enzymes sense oxygen, since the oxygen levels are critical for mediating their modification of the epigenetic program of a cell. Hypoxia inhibits these enzymes thus causing an increase in histone methylation and 5-methylcytosine $(5 \mathrm{mC})$ and a decrease in hydroxymethylcytosine $(5 \mathrm{hmC})$ [71] During periods of low oxygen tension, the messenger RNA (mRNA) and protein levels of a number of histone demethylases are increased via the hypoxia response elements (HREs) in their promoters [71]. Similar to hypoxia, inhibition of demethylases also occurs due to oxidative stress since the iron at the active site of these enzymes can be oxidized rendering the enzyme inactive [71] At the same time, oxidative stress decreases reduced ascorbate levels, which further attenuates enzymatic activity since ascorbate is a cofactor for these enzymes [72]. Finally, if the oxidative stress arises from dysfunctional mitochondria there will be less of 2-oxoglutarate, which is an essential cofactor for these enzymes [66].

Methylation of histone lysines and arginines in the $\mathrm{N}$ terminal tails, which protrude from the nucleosomes is involved in regulating a wide range of cellular processes [73-75]. Histone methylation can be involved in both activation and repression of gene expression depending on the residue modified and degree of methylation. For example, while histone 3 lysine 4 di- $(\mathrm{H} 3 \mathrm{~K} 4 \mathrm{me} 2)$ and trimethylation $(\mathrm{H} 3 \mathrm{~K} 4 \mathrm{me} 3)$ and histone 3 lysine 9 monomethylation (H3K9me1) are associated with transcriptionally active, open chromatin regions, histone 3 lysine 27 (H3K27) di- and trimethylation and H3K9 di- and trimethylation are associated transcriptionally silent, closed chromatin regions [71, 74, 76-78]. Histone tail methylation is a dynamic process maintained by the histone methyltransferases (HMTs) and demethylases. The majority of HMTs contain a conserved catalytic domain called SET (Suppressor of variegation, Enhancer of Zeste, Trithorax) [79]. Histone demethylases, on the other hand, can be divided into two classes: (1) KDM1 (Lysine (K) Demethylase1) family, also known as LSD1, are FAD-dependent amine oxidases, and (2) the Jumonji $\mathrm{C}(\mathrm{JmjC})$ domain containing demethylases (JHDMs), which are members of the dioxygenase superfamily of enzymes containing iron and are 2-oxoglutarate-dependent enzymes [73] [80]. The demethylation of lysines by JHDMs occurs by catalyzing the generation of oxidized $\mathrm{Fe}$ (reactive oxygen species) in the presence of oxygen, $\alpha$-ketoglutarate and ascorbate. These resultant species attack the methyl groups on histone lysines and produce unstable oxidized intermediates that spontaneously release formaldehyde, resulting in the removal of methyl groups from histone lysines [81]. Since LSD1 and JmjC histone demethlyases and TET family of DNA hydroxylases require oxygen to function, it is likely that oxygen concentration influences histone and DNA methylation.

Although the functional significance of these enzymes in relation to hypoxic response is not fully understood, a number of studies have demonstrated their involvement. It was recently shown that decreased H3K4me3 levels in clear-cell renal carcinoma were due to VHL inactivation, which was dependent on the constitutively active HIF- $2 \alpha$ and Jumonji/ARID Domain Containing Protein 1C (JARID1C). In VHL-/-cells, HIF induced JARIDIC expression, resulted in altered expression of hypoxia-responsive genes (HRGs) and reduced H3K4me3 levels at the promoters of IGFBP3, COL6A1, $D N A J C 12$, and GDF15 [82]. Interestingly, many 2oxoglutarate dioxygenases histone demethylases have hypoxia response elements (HREs) in their promoters and are induced by HIF-1 [83]. For example, JARID1B (KDM5B), JMJD1A (KDM3A), JMJD2B (KDM4B), and JMJD2C (KDM4C) are known to be direct HIF-1 target genes with robust HIF-1 binding to HREs in their promoters and upregulated expression under hypoxic conditions [84-87]. Under hypoxia, cells ectopically expressing JARID1B had decreased levels of H3K4 methylation [88]. Furthermore, JMJD1A was shown to regulate a subset of hypoxia-induced genes, including $A D M$ and $G D F 15$, by maintaining a lower level of $\mathrm{H} 3 \mathrm{~K} 9 \mathrm{me} 2$ at their promoter regions. JMJD1A (KDM3A) was also important for tumor growth in the hypoxic microenvironment of tumor xenografts [89]. In addition to 
upregulating the expression of certain demethylases, hypoxia also directly inhibits their enzyme activity because they require oxygen to carry out their enzymatic function. The compensatory upregulation of the histone demethylase expression under hypoxia and possibly with oxidative stress affords a way to identify the affected enzyme.

Inhibition of the Jumonji histone demethylases JMJD1A-C (KDM3A-C) and JMJD2A-D (KDM4A-D) with hypoxia as well as with the treatment of dioxygenase inhibitors, such as DMOG (N-(methoxyoxoacetyl)-glycinemethyl ester, DETANO (2,20-(hydroxynitrosohydrazono)bis-ethanimine) and ROS, resulted in increased levels of $\mathrm{H} 3 \mathrm{~K} 9 \mathrm{me} 2 / \mathrm{me}$ as well as H3K36me3 [90]. Exposure to nickel, an oxidative stresscausing agent can result in the distortion of a number of different post-translationally modified histone marks. A nontoxic dose of nickel was shown to significantly increase global levels of $\mathrm{H} 3 \mathrm{~K} 4 \mathrm{me} 3$ and $\mathrm{H} 3 \mathrm{~K} 9 \mathrm{me} 2$ [91] as well as cause spreading of $\mathrm{H} 3 \mathrm{~K} 9 \mathrm{me} 2$ causing aberrant gene silencing [78]. Thus, ROS produced during both hypoxia and hyperoxia can alter gene expression by affecting key enzymes involved histone post-translational modifications and DNA methylation, in addition to activating redox sensitive transcription factors.

\section{Conclusion}

In vitro cell culture at ambient atmospheric $\mathrm{O}_{2}$ levels ( $\left.21 \%\right)$ contribute to oxidative stress in both primary cells and immortalized cells. Furthermore, the pro-oxidant nature of the cell culture medium and decreased availability of antioxidants, combined with higher than normal physiological oxygen tension would result in net increase in ROS and inhibit several key $\mathrm{O}_{2}$ sensitive cofactors and transcription factors. However, decades of research have proven the utility of in vitro cell culture system, which is a rapid and cost-effective research tool [92-94]. The genetic and epigenetic changes observed in cancer cells in vivo has been accurately observed in in vitro studies [92-94]. Genome-wide studies have shown striking similarity in genome folding, DNA methylation, and histone modification profiles between in vitro cultures and the corresponding tumor samples $[94,95]$.

Although culturing the cells at the physiological $\mathrm{O}_{2}$ levels could potentially avoid the deleterious effects of high $\mathrm{O}_{2}$ levels, several practical difficulties exist. The distribution of $\mathrm{O}_{2}$ in vivo is organ and tissue specific. Moreover, organs such as skin [13], liver [5-7], and lung [2-4] show gradient distribution in oxygen level depending on extent of capillary blood supply. Furthermore, developmental stage specific oxygen levels are observed in placenta $[14,15]$. In addition, oxygen consumption rate by mammalian cells in in vitro culture ranges significantly between $<1$ and $>350 \mathrm{amol} \mathrm{cell}^{-1} \mathrm{~s}^{-1}$ [29]. The cellular $\mathrm{O}_{2}$ consumption rate in vitro depends on cell type, function, and metabolic activity and shows loose linear correlation with cell volume and protein content [29]. Moreover, the actual oxygen level the cell is exposed to in a culture dish is much lower than the surrounding atmospheric levels and the $\mathrm{O}_{2}$ levels further decrease when the cells proliferate [96]. Given the huge variation in $\mathrm{O}_{2}$ consumption rate of mammalian cells in vitro [29] and the broad physiological $\mathrm{O}_{2}$ levels in vivo [1], culturing cells at actual physiological $\mathrm{O}_{2}$ levels pose huge problems and is impractical. Alternatively, addition of multiple-time matched controls, gain or loss of function experiments, and usage of different cell types for the same treatment could attenuate experimental bias to some extent and would be a practically possible strategy. Immortalized cells cultured under high oxygen tension might show higher inflammatory response and redox imbalance. Therefore, care should be taken while studying inflammatory signaling and antioxidant activity of dietary molecules in immortalized cells as they could potentially exhibit elevated activity under in vitro culture conditions.

Acknowledgments This work was supported by National Institutes of Health, National Institute of Environmental Health Sciences Grants R01ES023174, R01ES024727, and P30ES000260 (SC) and National Institutes of Health, National Institute of Environmental Health Sciences Grants R01ES023174, R01ES022935, and P30ES000260 (MC).

\section{Compliance with Ethical Standards}

Conflict of Interest Authors declare no conflict of interest.

Human and Animal Rights and Informed Consent This article does not contain any studies with human or animal subjects performed by any of the authors.

\section{References}

1. Brahimi-Horn MC, Pouyssegur J. Oxygen, a source of life and stress. FEBS Lett. 2007;581(19):3582-91. doi:10.1016/j.febslet. 2007.06.018.

2. Le QT, Chen E, Salim A, Cao H, Kong CS, Whyte R, et al. An evaluation of tumor oxygenation and gene expression in patients with early stage non-small cell lung cancers. Clin Cancer Res: Off J Am Assoc Cancer Res. 2006;12(5):1507-14. doi:10.1158/10780432.CCR-05-2049.

3. Miller GW, Mugler 3rd JP, Altes TA, Cai J, Mata JF, de Lange EE, et al. A short-breath-hold technique for lung pO2 mapping with 3He MRI. Magn Reson Med: Off J Soc Magn Reson Med / Soc Mag Reson Med. 2010;63(1):127-36. doi:10.1002/mrm.22181.

4. Wild JM, Fichele S, Woodhouse N, Paley MN, Kasuboski L, van Beek EJ. 3D volume-localized pO2 measurement in the human lung with 3He MRI. Magn Reson Med: Off J Soc Magn Reson Med / Soc Magn Reson Med. 2005;53(5):1055-64. doi:10.1002/ mrm.20423.

5. Brooks AJ, Eastwood J, Beckingham IJ, Girling KJ. Liver tissue partial pressure of oxygen and carbon dioxide during partial hepatectomy. Br J Anaesth. 2004;92(5):735-7. doi:10.1093/bja/aeh112. 
6. Brooks AJ, Hammond JS, Girling K, Beckingham IJ. The effect of hepatic vascular inflow occlusion on liver tissue $\mathrm{pH}$, carbon dioxide, and oxygen partial pressures: defining the optimal clamp/ release regime for intermittent portal clamping. J Surg Res. 2007;141(2):247-51. doi:10.1016/j.jss.2006.10.054.

7. Leary TS, Klinck JR, Hayman G, Friend P, Jamieson NV, Gupta AK. Measurement of liver tissue oxygenation after orthotopic liver transplantation using a multiparameter sensor. A pilot study. Anaesthesia. 2002;57(11):1128-33.

8. Muller M, Padberg W, Schindler E, Sticher J, Osmer C, Friemann $\mathrm{S}$, et al. Renocortical tissue oxygen pressure measurements in patients undergoing living donor kidney transplantation. Anesth Analg. 1998;87(2):474-6.

9. Dings J, Meixensberger J, Jager A, Roosen K. Clinical experience with 118 brain tissue oxygen partial pressure catheter probes. Neurosurgery. 1998;43(5):1082-95.

10. Schultheiss R, Leuwer R, Leniger-Follert E, Wassmann H, Wullenweber R. Tissue pO2 of human brain cortex-method, basic results and effects of pentoxifylline. Angiology. 1987;38(3):221-5.

11. Siegfried CJ, Shui YB, Holekamp NM, Bai F, Beebe DC. Oxygen distribution in the human eye: relevance to the etiology of openangle glaucoma after vitrectomy. Invest Ophthalmol Vis Sci. 2010;51(11):5731-8. doi:10.1167/iovs.10-5666.

12. Harrison JS, Rameshwar P, Chang V, Bandari P. Oxygen saturation in the bone marrow of healthy volunteers. Blood. 2002;99(1):394.

13. Wang W, Winlove CP, Michel CC. Oxygen partial pressure in outer layers of skin of human finger nail folds. J Physiol. 2003;549(Pt 3): 855-63. doi:10.1113/jphysiol.2002.037994.

14. Jauniaux E, Watson A, Burton G. Evaluation of respiratory gases and acid-base gradients in human fetal fluids and uteroplacental tissue between 7 and 16 weeks' gestation. Am J Obstet Gynecol. 2001;184(5):998-1003. doi:10.1067/mob.2001.111935.

15. Jauniaux E, Watson AL, Hempstock J, Bao YP, Skepper JN, Burton GJ. Onset of maternal arterial blood flow and placental oxidative stress. A possible factor in human early pregnancy failure. Am $\mathrm{J}$ Pathol. 2000;157(6):2111-22. doi:10.1016/S0002-9440(10)64849-3.

16. Ames BN, Shigenaga MK, Hagen TM. Oxidants, antioxidants, and the degenerative diseases of aging. Proc Natl Acad Sci U S A. 1993;90(17):7915-22.

17. Atkuri KR, Herzenberg LA, Herzenberg LA. Culturing at atmospheric oxygen levels impacts lymphocyte function. Proc Natl Acad Sci U S A. 2005;102(10):3756-9. doi:10.1073/pnas. 0409910102

18. Atkuri KR, Herzenberg LA, Niemi AK, Cowan T, Herzenberg LA. Importance of culturing primary lymphocytes at physiological oxygen levels. Proc Natl Acad Sci U S A. 2007;104(11):4547-52. doi: 10.1073/pnas.0611732104.

19. Itahana K, Zou Y, Itahana Y, Martinez JL, Beausejour C, Jacobs JJ, et al. Control of the replicative life span of human fibroblasts by p16 and the polycomb protein Bmi-1. Mol Cell Biol. 2003;23(1):389401.

20. Parrinello S, Samper E, Krtolica A, Goldstein J, Melov S, Campisi J. Oxygen sensitivity severely limits the replicative lifespan of murine fibroblasts. Nat Cell Biol. 2003;5(8):741-7. doi:10.1038/ ncb1024.

21. Saito H, Hammond AT, Moses RE. The effect of low oxygen tension on the in vitro-replicative life span of human diploid fibroblast cells and their transformed derivatives. Exp Cell Res. 1995;217(2): 272-9. doi:10.1006/excr.1995.1087.

22. Carrera S, de Verdier PJ, Khan Z, Zhao B, Mahale A, Bowman KJ, et al. Protection of cells in physiological oxygen tensions against DNA damage-induced apoptosis. J Biol Chem. 2010;285(18): 13658-65. doi:10.1074/jbc.M109.062562.

23. Guo CW, Kawakatsu M, Idemitsu M, Urata Y, Goto S, Ono Y, et al. Culture under low physiological oxygen conditions improves the stemness and quality of induced pluripotent stem cells. J Cell Physiol. 2013;228(11):2159-66. doi:10.1002/jcp.24389.

24. Ivanovic Z. Hypoxia or in situ normoxia: the stem cell paradigm. J Cell Physiol. 2009;219(2):271-5. doi:10.1002/jcp.21690.

25. Shay JW, Wright WE. Senescence and immortalization: role of telomeres and telomerase. Carcinogenesis. 2005;26(5):867-74. doi:10.1093/carcin/bgh296.

26. Shay JW, Wright WE, Werbin H. Defining the molecular mechanisms of human cell immortalization. Biochim Biophys Acta. 1991;1072(1):1-7.

27. Halliwell B. Oxidative stress in cell culture: an under-appreciated problem? FEBS Lett. 2003;540(1-3):3-6.

28. Halliwell B. Cell culture, oxidative stress, and antioxidants: avoiding pitfalls. Biomed J. 2014;37(3):99-105. doi:10.4103/ 2319-4170.128725.

29. Wagner BA, Venkataraman S, Buettner GR. The rate of oxygen utilization by cells. Free Radic Biol Med. 2011;51(3):700-12. doi: 10.1016/j.freeradbiomed.2011.05.024.

30. Poyton RO, Ball KA, Castello PR. Mitochondrial generation of free radicals and hypoxic signaling. Trends Endocrinol Metab. 2009;20(7):332-40. doi:10.1016/j.tem.2009.04.001.

31. Leist M, Raab B, Maurer S, Rosick U, Brigelius-Flohe R. Conventional cell culture media do not adequately supply cells with antioxidants and thus facilitate peroxide-induced genotoxicity. Free Radic Biol Med. 1996;21(3):297-306.

32. Grzelak A, Rychlik B, Bartosz G. Reactive oxygen species are formed in cell culture media. Acta Biochim Pol. 2000;47(4):1197-8.

33. Carreau A, El Hafny-Rahbi B, Matejuk A, Grillon C, Kieda C. Why is the partial oxygen pressure of human tissues a crucial parameter? Small molecules and hypoxia. J Cell Mol Med. 2011;15(6):123953. doi:10.1111/j.1582-4934.2011.01258.x.

34. Sesti F, Tsitsilonis OE, Kotsinas A, Trougakos IP. Oxidative stressmediated biomolecular damage and inflammation in tumorigenesis. In Vivo. 2012;26(3):395-402.

35. Fedorova M, Bollineni RC, Hoffmann R. Protein carbonylation as a major hallmark of oxidative damage: update of analytical strategies. Mass Spectrom Rev. 2014;33(2):79-97. doi:10.1002/mas.21381.

36. Chakravarthi S, Jessop CE, Bulleid NJ. The role of glutathione in disulphide bond formation and endoplasmic-reticulum-generated oxidative stress. EMBO Rep. 2006;7(3):271-5. doi:10.1038/sj. embor.7400645.

37. Meng XX, Yao M, Zhang XD, Xu HX, Dong Q. ER stress-induced autophagy in melanoma. Clin Exp Pharmacol Physiol. 2015;42(8): 811-6. doi:10.1111/1440-1681.12436.

38. Cadet J, Ravanat JL, TavernaPorro M, Menoni H, Angelov D. Oxidatively generated complex DNA damage: tandem and clustered lesions. Cancer Lett. 2012;327(1-2):5-15. doi:10.1016/j. canlet.2012.04.005.

39. Chen Q, Fischer A, Reagan JD, Yan LJ, Ames BN. Oxidative DNA damage and senescence of human diploid fibroblast cells. Proc Natl Acad Sci U S A. 1995;92(10):4337-41.

40. Kryston TB, Georgiev AB, Pissis P, Georgakilas AG. Role of oxidative stress and DNA damage in human carcinogenesis. Mutat Res. 2011;711(1-2):193-201. doi:10.1016/j.mrfmmm.2010.12. 016.

41. van Gent DC, Hoeijmakers JH, Kanaar R. Chromosomal stability and the DNA double-stranded break connection. Nat Rev Genet. 2001;2(3):196-206. doi:10.1038/35056049.

42. Wang CY, Liu LN, Zhao ZB. The role of ROS toxicity in spontaneous aneuploidy in cultured cells. Tissue Cell. 2013;45(1):47-53. doi:10.1016/j.tice.2012.09.004.

43. Pires AO, Neves-Carvalho A, Sousa N, Salgado AJ. The secretome of bone marrow and wharton jelly derived mesenchymal stem cells induces differentiation and neurite outgrowth in SH-SY5Y Cells. Stem Cells Int. 2014;2014:438352. doi:10.1155/2014/438352. 
44. Teixeira FG, Panchalingam KM, Anjo SI, Manadas B, Pereira R, Sousa N, et al. Do hypoxia/normoxia culturing conditions change the neuroregulatory profile of Wharton jelly mesenchymal stem cell secretome? Stem Cell Res Ther. 2015;6(1):133. doi:10.1186/ s13287-015-0124-z.

45. Forsyth NR, Musio A, Vezzoni P, Simpson AH, Noble BS, McWhir J. Physiologic oxygen enhances human embryonic stem cell clonal recovery and reduces chromosomal abnormalities. Cloning Stem Cells. 2006;8(1):16-23. doi:10.1089/clo.2006.8.16.

46. Liu AM, Qu WW, Liu X, Qu CK. Chromosomal instability in in vitro cultured mouse hematopoietic cells associated with oxidative stress. Am J Blood Res. 2012;2(1):71-6.

47. von Zglinicki T, Saretzki G, Docke W, Lotze C. Mild hyperoxia shortens telomeres and inhibits proliferation of fibroblasts: a model for senescence? Exp Cell Res. 1995;220(1):186-93. doi:10.1006/ excr.1995.1305.

48. Haddad H, Windgassen D, Ramsborg CG, Paredes CJ, Papoutsakis ET. Molecular understanding of oxygen-tension and patientvariability effects on ex vivo expanded $\mathrm{T}$ cells. Biotechnol Bioeng. 2004;87(4):437-50. doi:10.1002/bit.20166.

49. Martinez I, Nedredal GI, Oie CI, Warren A, Johansen O, Le Couteur DG, et al. The influence of oxygen tension on the structure and function of isolated liver sinusoidal endothelial cells. Comp Hepatol. 2008;7:4. doi:10.1186/1476-5926-7-4.

50. Carreau A, Kieda C, Grillon C. Nitric oxide modulates the expression of endothelial cell adhesion molecules involved in angiogenesis and leukocyte recruitment. Exp Cell Res. 2011;317(1):29-41. doi:10.1016/j.yexcr.2010.08.011.

51. Mostafa SS, Papoutsakis ET, Miller WM. Oxygen tension modulates the expression of cytokine receptors, transcription factors, and lineage-specific markers in cultured human megakaryocytes. Exp Hematol. 2001;29(7):873-83.

52. Espinosa-Diez C, Miguel V, Mennerich D, Kietzmann T, SanchezPerez P, Cadenas S, et al. Antioxidant responses and cellular adjustments to oxidative stress. Redox Biol. 2015;6:183-97. doi:10.1016/ j.redox.2015.07.008.

53. Semenza GL. Oxygen-regulated transcription factors and their role in pulmonary disease. Respir Res. 2000;1(3):159-62. doi:10.1186/ rr27.

54. Benhar M, Engelberg D, Levitzki A. ROS, stress-activated kinases and stress signaling in cancer. EMBO Rep. 2002;3(5):420-5. doi: 10.1093/embo-reports/kvf094.

55. Matsuzawa A, Ichijo H. Stress-responsive protein kinases in redoxregulated apoptosis signaling. Antioxid Redox Signal. 2005;7(34):472-81. doi:10.1089/ars.2005.7.472.

56. Patten DA, Lafleur VN, Robitaille GA, Chan DA, Giaccia AJ, Richard DE. Hypoxia-inducible factor-1 activation in nonhypoxic conditions: the essential role of mitochondrial-derived reactive oxygen species. Mol Biol Cell. 2010;21(18):3247-57. doi:10.1091/ mbc.E10-01-0025.

57. Busuttil RA, Rubio M, Dolle ME, Campisi J, Vijg J. Oxygen accelerates the accumulation of mutations during the senescence and immortalization of murine cells in culture. Aging Cell. 2003;2(6): 287-94.

58. Ho HY, Cheng ML, Cheng PF, Chiu DT. Low oxygen tension alleviates oxidative damage and delays cellular senescence in G6PD-deficient cells. Free Radic Res. 2007;41(5):571-9. doi:10. 1080/10715760601184819.

59. Toussaint O, Weemaels G, Debacq-Chainiaux F, ScharffetterKochanek K, Wlaschek M. Artefactual effects of oxygen on cell culture models of cellular senescence and stem cell biology. J Cell Physiol. 2011;226(2):315-21. doi:10.1002/jcp.22416.

60. Kondoh H, Lleonart ME, Bernard D, Gil J. Protection from oxidative stress by enhanced glycolysis; a possible mechanism of cellular immortalization. Histol Histopathol. 2007;22(1):85-90.
61. Kondoh H, Lleonart ME, Gil J, Wang J, Degan P, Peters G, et al. Glycolytic enzymes can modulate cellular life span. Cancer Res. 2005;65(1):177-85.

62. Kondoh H, Lleonart ME, Nakashima Y, Yokode M, Tanaka M, Bernard D, et al. A high glycolytic flux supports the proliferative potential of murine embryonic stem cells. Antioxid Redox Signal. 2007;9(3):293-9. doi:10.1089/ars.2007.9.ft-14.

63. Jagannathan L, Jose CC, Arita A, Kluz T, Sun H, Zhang X, et al. Nuclear factor kappaB1/RelA mediates inflammation in human lung epithelial cells at atmospheric oxygen levels. J Cell Physiol. 2015. doi:10.1002/jcp. 25262.

64. Favaro E, Ramachandran A, McCormick R, Gee H, Blancher C, Crosby M, et al. MicroRNA-210 regulates mitochondrial free radical response to hypoxia and krebs cycle in cancer cells by targeting iron sulfur cluster protein ISCU. PLoS One. 2010;5(4):e10345. doi: 10.1371/journal.pone.0010345.

65. Kolamunne RT, Clare M, Griffiths HR. Mitochondrial superoxide anion radicals mediate induction of apoptosis in cardiac myoblasts exposed to chronic hypoxia. Arch Biochem Biophys. 2011;505(2): 256-65. doi:10.1016/j.abb.2010.10.015.

66. Selivanov VA, Votyakova TV, Pivtoraiko VN, Zeak J, Sukhomlin $\mathrm{T}$, Trucco M, et al. Reactive oxygen species production by forward and reverse electron fluxes in the mitochondrial respiratory chain. PLoS Comput Biol. 2011;7(3):e1001115. doi:10.1371/journal.pcbi. 1001115.

67. Semenza GL. Hypoxia-inducible factors in physiology and medicine. Cell. 2012;148(3):399-408. doi:10.1016/j.cell.2012.01.021.

68. Melvin A, Rocha S. Chromatin as an oxygen sensor and active player in the hypoxia response. Cell Signal. 2012;24(1):35-43. doi:10.1016/j.cellsig.2011.08.019.

69. Davidson TL, Chen H, Di Toro DM, D'Angelo G, Costa M. Soluble nickel inhibits HIF-prolyl-hydroxylases creating persistent hypoxic signaling in A549 cells. Mol Carcinog. 2006;45(7):479_ 89. doi:10.1002/mc.20176.

70. Ke Q, Costa M. Hypoxia-inducible factor-1 (HIF-1). Mol Pharmacol. 2006;70(5):1469-80. doi:10.1124/mol.106.027029.

71. Hancock RL, Dunne K, Walport LJ, Flashman E, Kawamura A. Epigenetic regulation by histone demethylases in hypoxia. Epigenomics. 2015:1-21. doi: 10.2217/epi.15.24.

72. Chervona $\mathrm{Y}$, Costa $\mathrm{M}$. The control of histone methylation and gene expression by oxidative stress, hypoxia, and metals. Free Radic Biol Med. 2012;53(5):1041-7. doi:10.1016/j.freeradbiomed.2012. 07.020 .

73. Klose RJ, Kallin EM, Zhang Y. JmjC-domain-containing proteins and histone demethylation. Nat Rev Genet. 2006;7(9):715-27. doi: $10.1038 / \mathrm{nrg} 1945$.

74. Schneider R, Grosschedl R. Dynamics and interplay of nuclear architecture, genome organization, and gene expression. Genes Dev. 2007;21(23):3027-43. doi:10.1101/gad.1604607.

75. Bernstein BE, Mikkelsen TS, Xie X, Kamal M, Huebert DJ, Cuff J, et al. A bivalent chromatin structure marks key developmental genes in embryonic stem cells. Cell. 2006;125(2):315-26. doi:10. 1016/j.cell.2006.02.041.

76. Barski A, Cuddapah S, Cui K, Roh TY, Schones DE, Wang Z, et al. High-resolution profiling of histone methylations in the human genome. Cell. 2007;129(4):823-37. doi:10.1016/j.cell.2007.05.009.

77. Cuddapah S, Jothi R, Schones DE, Roh TY, Cui K, Zhao K. Global analysis of the insulator binding protein CTCF in chromatin barrier regions reveals demarcation of active and repressive domains. Genome Res. 2009;19(1):24-32. doi:10. 1101/gr.082800.108.

78. Jose CC, Xu B, Jagannathan L, Trac C, Mallela RK, Hattori T, et al. Epigenetic dysregulation by nickel through repressive chromatin domain disruption. Proc Natl Acad Sci U S A. 2014;111(40): 14631-6. doi:10.1073/pnas.1406923111. 
79. Albert M, Helin K. Histone methyltransferases in cancer. Semin Cell Dev Biol. 2010;21(2):209-20. doi:10.1016/j.semcdb.2009. 10.007 .

80. Pedersen MT, Helin K. Histone demethylases in development and disease. Trends Cell Biol. 2010;20(11):662-71. doi:10.1016/j.tcb. 2010.08.011.

81. Chen H, Costa M. Iron- and 2-oxoglutarate-dependent dioxygenases: an emerging group of molecular targets for nickel toxicity and carcinogenicity. Biometals. 2009;22(1):191-6. doi:10. 1007/s10534-008-9190-3.

82. Niu X, Zhang T, Liao L, Zhou L, Lindner DJ, Zhou M, et al. The von Hippel-Lindau tumor suppressor protein regulates gene expression and tumor growth through histone demethylase JARID1C. Oncogene. 2012;31(6):776-86. doi:10.1038/onc.2011.266.

83. Yang J, Ledaki I, Turley H, Gatter KC, Montero JC, Li JL, et al. Role of hypoxia-inducible factors in epigenetic regulation via histone demethylases. Ann N Y Acad Sci. 2009;1177:185-97. doi:10. 1111/j.1749-6632.2009.05027.x.

84. Pollard PJ, Loenarz C, Mole DR, McDonough MA, Gleadle JM, Schofield CJ, et al. Regulation of Jumonji-domain-containing histone demethylases by hypoxia-inducible factor (HIF)-1alpha. Biochem J. 2008;416(3):387-94. doi:10.1042/BJ20081238.

85. Sar A, Ponjevic D, Nguyen M, Box AH, Demetrick DJ. Identification and characterization of demethylase JMJD1A as a gene upregulated in the human cellular response to hypoxia. Cell Tissue Res. 2009;337(2):223-34. doi:10.1007/s00441-009-0805-y.

86. Krieg AJ, Rankin EB, Chan D, Razorenova O, Fernandez S, Giaccia AJ. Regulation of the histone demethylase JMJD1A by hypoxia-inducible factor 1 alpha enhances hypoxic gene expression and tumor growth. Mol Cell Biol. 30(1):344-53. doi: 10.1128/ MCB.00444-09.

87. Guo X, Lu J, Wang Y, Gui Y, Duan X, Cai Z. Ascorbate antagonizes nickel ion to regulate JMJD1A expression in kidney cancer cells. Acta Biochim Biophys Sin (Shanghai). 44(4):330-8. doi: 10.1093/ abbs/gms004.
88. Xia X, Lemieux ME, Li W, Carroll JS, Brown M, Liu XS, et al. Integrative analysis of HIF binding and transactivation reveals its role in maintaining histone methylation homeostasis. Proc Natl Acad Sci U S A. 2009;106(11):4260-5. doi:10.1073/pnas. 0810067106.

89. Krieg AJ, Rankin EB, Chan D, Razorenova O, Fernandez S, Giaccia AJ. Regulation of the histone demethylase JMJD1A by hypoxia-inducible factor 1 alpha enhances hypoxic gene expression and tumor growth. Mol Cell Biol. 2010;30(1):344-53. doi:10.1128/ MCB.00444-09.

90. Tausendschon M, Dehne N, Brune B. Hypoxia causes epigenetic gene regulation in macrophages by attenuating Jumonji histone demethylase activity. Cytokine. 53(2):256-62. doi: 10.1016/j.cyto. 2010.11.002.

91. Zhou X, Li Q, Arita A, Sun H, Costa M. Effects of nickel, chromate, and arsenite on histone 3 lysine methylation. Toxicol Appl Pharmacol. 2009;236(1):78-84. doi:10.1016/j.taap.2009.01.009.

92. Gazdar AF, Gao B, Minna JD. Lung cancer cell lines: Useless artifacts or invaluable tools for medical science? Lung Cancer. 2010;68(3):309-18. doi:10.1016/j.lungcan.2009.12.005.

93. Gazdar AF, Girard L, Lockwood WW, Lam WL, Minna JD. Lung cancer cell lines as tools for biomedical discovery and research. J Natl Cancer Inst. 2010;102(17):1310-21. doi:10.1093/jnci/djq279.

94. Wistuba II, Bryant D, Behrens C, Milchgrub S, Virmani AK, Ashfaq R, et al. Comparison of features of human lung cancer cell lines and their corresponding tumors. Clin Cancer Res: Off J Am Assoc Cancer Res. 1999;5(5):991-1000.

95. Kim HS, Sung YJ, Paik S. Cancer cell line panels empower genomics-based discovery of precision cancer medicine. Yonsei Med J. 2015;56(5):1186-98. doi:10.3349/ymj.2015.56.5.1186.

96. Naciri M, Kuystermans D, Al-Rubeai M. Monitoring $\mathrm{pH}$ and dissolved oxygen in mammalian cell culture using optical sensors. Cytotechnology. 2008;57(3):245-50. doi:10.1007/s10616-0089160-1. 